\begin{tabular}{|c|c|c|c|c|c|c|}
\hline \multirow{4}{*}{ Impact Factor: } & ISRA (India) & $=3.117$ & SIS (USA) & $=0.912$ & ICV (Poland) & $=6.630$ \\
\hline & ISI (Dubai, UAE & $=0.829$ & РИНЦ (Russia & $=0.156$ & PIF (India) & $=1.940$ \\
\hline & GIF (Australia) & $=0.564$ & ESJI (KZ) & $=8.716$ & IBI (India) & $=4.260$ \\
\hline & JIF & $=1.500$ & SJIF (Morocco & $=5.667$ & OAJI (USA) & $=0.350$ \\
\hline
\end{tabular}

\section{SOI: $\underline{1.1 / \text { TAS }}$ DOI: $10.15863 /$ TAS \\ International Scientific Journal Theoretical \& Applied Science}

\author{
p-ISSN: 2308-4944 (print) e-ISSN: 2409-0085 (online) \\ Year: 2019 Issue: $07 \quad$ Volume: 75
}

Published: $30.07 .2019 \quad$ http://T-Science.org
QR - Issue

QR - Article
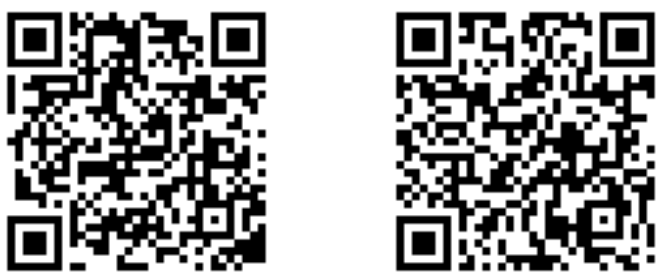

Z.M. Juraev

National University of Uzbekistan,

Senior lecturer,

Tashkent, Republic of Uzbekistan

\title{
THE INTENTION - A CHOICE OR THE DOCTRINE OF ELECTION IN MAVARDI PRODUCT «A L-AHKOM-AS-SULTONIYA VA-L-VALOYOT AD-DINIYA»
}

Abstract: In this article analyzed the intention - a choice or the doctrine of election . In article is considered scientists used Ahkom as the main theoretical source in creating of their works on state governing, Mavardi's work "Ahkom consists of 20 chapters and 109 sections which the content and structure of the themes are given completely and logically consequently.

Key words: al-Mavardi, statehood, government, sunna, imam, sultan, vizier, emir, cadi (judge), manuscript, Allah, prophet, rasul, the Koran, hadith, shariah, ahkam, islam, valayat, ahl as sunnah va-l-jamo'a, madhhab, religion, aqidah, aqd, creed (e'tiqod), sunnah, faith (farz), vajib, salat; political information law, election, choise (tanlov), truce (sulh), advice (mashvarat), volition (ixtiyor), policy, Islamic law, public administration, contract.

Language: English

Citation: Juraev, Z. M. (2019). The intention - a choice or the doctrine of election in Mavardi product «A 1ahkom-as-sultoniya va-l-valoyot ad-diniya». ISJ Theoretical \& Applied Science, 07 (75), 446-453.

Soi: http://s-o-i.org/1.1/TAS-07-75-72 Doi: crossef https://dx.doi.org/10.15863/TAS.2019.07.75.72

Classifiers: Geography. History. Oceanology. Meteorology.

\section{Introduction}

The well-known work of Mavardi is called «Alahkom-as-sultoniya va-l-valoyot ad-diniya» (the canons of sultanate and religious managements further as "Ahkom"), its manuscript is in the fund of manuscripts and rare publications of National Library of Uzbekistan and consists of $185^{\mathrm{a}-\mathrm{b}}$ pages; and the manuscript which is in the Institute of Oriental studies named after Abu Raykhan Biruni of the AS of the Republic of Uzbekistan, consists of $107^{\mathrm{a}-\mathrm{b}}$ pages. In the given work about organization of the government and election of its head it is possible to say that according to historical source study, if in any state the elective and registered legislation and the selective system of statehood is observed, such state or the doctrine in work is considered as patriotic, fair and taking care of the people. The given source is also considered as the very first introduction of the doctrine, which has historically developed in X-XI century.
Materials and methods

The selective concept al-ikhtiyor [the selection of the most worthy and the best among the nation, selection or freedom of choice] is especially important historical basis of elective principle. In this work, the election of imams is considered as a desirable choice of the population - umma (nations) (ahl-ul-ikhtiyor) that is an indicator of political-legal task of the state office-work.

Mavardi expresses his opinion on worthy candidates for the post of imam - the head of the country, and elections of the most worthy one among the candidates, and shows two best ways for elections on a lawful basis:

The first one - choice of the worthy head by means of meeting of wise men - «Ahl ul-khal va-l-akd li-l-ikhtiyor».

The second one - determination of legality or illegality of choice of the previous imam-head.

The members of the socio-political administrative representation should accept the selective-compulsory status of the head of the country. 


\begin{tabular}{|c|c|c|c|c|c|c|}
\hline \multirow{4}{*}{ Impact Factor: } & ISRA (India) & $=3.117$ & SIS (USA) & $=0.912$ & ICV (Poland) & $=6.630$ \\
\hline & ISI (Dubai, UAE & $=0.829$ & РИНЦ (Russia & $=0.156$ & PIF (India) & $=1.940$ \\
\hline & GIF (Australia) & $=0.564$ & ESJI (KZ) & $=8.716$ & IBI (India) & $=4.260$ \\
\hline & JIF & $=1.500$ & SJIF (Morocco & $=5.667$ & OAJI (USA) & $=0.350$ \\
\hline
\end{tabular}

Mavardi in "Ahkom" writes the following: «before the most worthy one is elected among the people and becomes the head of the country, the social groups are basically subdivided into three stratas» [17].

The first strata - structure of «ahl ul-ikhtiyor lilimom» which chooses the worthy candidate for the head of the country: Mavardi shows the norms of election of the candidates, who come from common people and considers that this candidate should have the best virtues to become the imam. Besides, he considers that there should be a certain administrative institution for election campaign, indications of successor to the throne, its definitions and selective consideration.

As a result of this, he has laid the foundation for the special selective establishment - «al-akhom makhkamat istikhyor al-khossa», carrying out the activity connected with elections, and has defined its theoretical parties. In its turn, as a political-legal and practical basis of the above-stated establishment, he has developed the thorough system of rules and laws of selective process. According to the Mavardi's doctrine of intention:

- The council-committee developing the general laws and rules of selective system on management of the state at the election of sultan ("kavoidi akhom assultoniya li-l-ikhtiyor»));

- Eminent wise men, politicians, mutaccalims, jurists who have been chosen from the territorial unit of the country and the meeting of members of presidium («zhumkhuri ahl al-akd va-l-khal min kulli balad»);

- Meeting of politicians, jurists chosen from the territory of country for an establishment of control over the meeting of electoral committee («zhumkhur al-fukakho va-l-mutakallimin»);

- Meeting which gives the consent of associates of the Prophet («ahli shuro» - the deputies of Oliy Majlis (Parliament) or meeting of advisers);

- Meeting of ulema - tabeins who are the contemporaries of khulafoi roshidin - great scientists of that period («ulema al-asr» and «ulema attabein»);

- The meeting showing the successors to the throne on the conclusions of the special elective conclusion («akhkom al-ukud al-khossa») on a post of the head of the country from recognized a priori candidates;

- Consultative meeting of scientists of that time («al-majlisu ahl al-mashvarat»);

- Meeting which considers a post of the head of the country and a condition of appointment to this post («akhl al-khal va-l-akd li-l-imam»);

- The meeting, which is summing up the conclusions of members of an academic council and the elections inspector for the election and appointment of the head of the country («akh lattakhkim li-l-ikhtiyor»);
- Elective presidium of the head of the country («akhl al-ikhtiyor li-l-imam »);

- Special elective presidium for the election of the head of the country («akhl al-khal va-l-akd li-likhtiyor al-imam al-khossa»);

- A mutual consent and election of special electoral presidium consisting of five, six, three, two, of one member ("rizo li-l-ikhtiyor");

- Responsible management for the elective process, consisting of known scientists of that period («al-majlisu ahl al-mashvarat»).

In Mavardi product "Ahkom" the politicallylegal bases of elections and a choice of the worthy candidate for the post of the head of country - the imam and participation in elective process of the aforementioned authorized bodies system - members of committee are specified. Better to say, the representatives of the first strata choose worthy candidate for the post of the head of country on the basis of such various criteria as kindness in relation to the people, mercy, responsibility for safety of society and people, understanding of the time and political system, and all of them should come to a common opinion - ijmo.

The second strata- the representatives- selected, i.e. group of candidates for the post of the head of country - «ahl al-imam», and among them, the most worthy is elected for the post of the head of country.

The third strata - unauthorized persons, remained out of aforementioned two Muslim societies, and it is impossible to force them to elective process of the head of the country - imam. As this third strata is considered as authorized representatives of socially neutral society, and they are free citizens of the country [8].

After presence of candidates on the post of the head of country - the imam, the legal, political and standard conditions for two groups are defined.

Mavardi in "Akhkom" puts the following three standard requirements and conditions on responsibility of «al-akhkom mukhokamat istihyor alimom al-khossa» before the special elective group, showing the candidate on a post of the head of country:

1.The head of the country should be a fair, clever, formed and intelligent person.

2.He should own the necessary knowledge, which is required for fair management during his leadership. It is required to specify a family tree of the candidate, activity of office-work, the knowledge, supervising ability and experience.

3.If the number of candidates on a post of the head of the country - the imam exceeds one, it is necessary to choose the most worthy one for the country and society government [9].

The electors of candidates for the post of the head of country - the imam, are required to choose the most worthy, necessary on circumstances, intelligent, the most capable and distinguishing special questions. 


\begin{tabular}{|c|c|c|c|c|c|c|}
\hline \multirow{4}{*}{ Impact Factor: } & ISRA (India) & $=3.117$ & SIS (USA) & $=0.912$ & ICV (Poland) & $=6.630$ \\
\hline & ISI (Dubai, UAE & $=0.829$ & РИНЦ (Russia & $=0.156$ & PIF (India) & $=1.940$ \\
\hline & GIF (Australia) & $=0.564$ & ESJI (KZ) & $=8.716$ & IBI (India) & $=4.260$ \\
\hline & JIF & $=1.500$ & SJIF (Morocce & $=5.667$ & OAJI (USA) & $=0.350$ \\
\hline
\end{tabular}

They should own strong mind to define the possible head - the imam, among the candidates.

According to Mavardi, the capital electors of the head of the country - the imam, among the candidates have no advantage before the electors of regional meeting. Perhaps, all citizens of the country have equal political options, and in their turn, they also can be elected. It is necessary to appoint the impartial person for definition of a choice of the worthy candidate for the post of the head of the country. Similar to this, the head of the country - the imam, is elected not because of religious reasons, but because of customs and ceremonies. In the course of elections, the regional voters, which names are specified as the imam - the head of the country, should be one of the «members of meeting of presidium, mutakallim, jurist and an eminent wise man - politician, selected among regional units of the country», the managing director on business management of selective campaign and the authorized representative. It is even provided, that the regional representatives as the candidate from «zhumkhur al-fukaro va-l-mutakallimin» can operate the presidium for the management of business of selective campaign or they are chosen as a member.

As he is required within the limits of powers of the head of the country - the imam, to have sufficient knowledge for the post of imam - the head of the country, from this follows, whether he is worthy for this post or not. He should consider which of the persons of the given region owns sufficient both worthy knowledge and experience for the management of business of the head of the country [10].

In Mavardi's work "Akhkom" in "section about two ways of an election of imam - the head of the country» it is said about the rights and duties of imomat and hilofat - the government, elective means «Ashobi ikhtiyor ahl al-akd va-l-hol» or the choice intention of the former imam - the head after the manner of election can be one of two forms.

As indicated in Mavardi's work "Ahkom", the imomat (government) organized by means of an elective way and within the limits of its organizational rules has some opinions:

1.If the main elective state jury «Ashobi ikhtiyor ahl al-akd va-l-khol» will not receive a universal recognition, then it is not in forces to organize and found the imomat - the state government, because the head of the country through this choice obtains an allUnion recognition and should be selected by means of ijmo.

However, the applied way bayat - a choice, at election of Its majesty Abu Bakra on a post of the head of the country - the imam, was not in the aforementioned form. Bayat is such a way of a choice, at which the present persons did bayat to him (elected him as the head of the country - the imam), and they did not wait the bayat from the absent persons.
2.The least number of members of the elective council, the special elective jury, required for the establishment of the state presidency, should be not less than five. The choice is considered natural, if they come to a common opinion, and the consent of one of them to a post of the head of the country $-\ll u d u l i$ birrizo li-l-ikhtiyor» is taken into consideration. Mavardi, concerning this point of view, furnishes two proofs:

The first proof: at election of Its majesty Abu Bakr by means of bayat (a general recognition, a choice) the number of officials was five. Subsequently the people have recognized this choice of officials. The aforementioned persons were Umar ibn al Hattab, Abu Ubajda ibn Zharroh, Sayyid ibn Khuzayir, Bishir ibn Sad and released slave Abu Khuzayfy Solim.

The second proof: Its majesty Umar could convoke the meeting «al-majlisu ahl il-mashvarat» consisting of six members -wise men «ahl al-khal val-akd li-l-imam», to give consent bayat in a kind "rizo" to one of councillors on a choice of the head of the country - the imam.

This theory is considered as the outlook of Islamic jurists - mutacallims from Basra «zhumkhur al-fukakho va-l-mutakallimin».

1.Other scientists from Kufa preferred to legalize the head of the country - the imam, by three persons of council. This theory allegedly was considered, as in the marriage union by means of one vali and two witnesses to legalize the marriage union. The recognition of khalifat is considered supposedly valid if two of the three witnesses give the consent, and the third becomes the head of the country. They adhered and protected such opinion: if two witnesses give bayat to the imam - to the head of the country, then the country leaders and the agreement of imamat is considered as brought to perfection.

2.According to scientists of tobeiin «ulamoi asr $v a$-t-tobeiin» - contemporaries of khulafoi roshidin which were considered as great scientists of that time it was possible to found the imamat- the country management, by one person-. As a matter of fact, Its majesty Abbos said: "Give me the hands, and I give to you bayat» to Its majesty Ali. In this case, people have given bayat to the son of the uncle of Its majesty prophet Mohammed. At occurrence of this case, there were no doubts. It also was said: Abbos was the judge, and the decision (word) of the most preferable person is considered as making impression [11].

Mavardi in work "Akhkom" results the following doctrines about the ways of election of the head of the country - the imam: the elective council «Ahl al-akd va-l-khal lil-ikhtiyori imam» when they gather for the elections of the head of the country - the imam, they pay attention to available characteristics of candidates for the imam - «akhvoli ahl al-imam». The voters should not show slowness, i.e. should be resolute at bayat to the imam - to the head of the country, who possesses all virtues for this post, 


\begin{tabular}{|c|c|c|c|c|c|c|}
\hline \multirow{4}{*}{ Impact Factor: } & ISRA (India) & $=3.117$ & SIS (USA) & $=0.912$ & ICV (Poland) & $=6.630$ \\
\hline & ISI (Dubai, UAE & $=0.829$ & РИНЦ (Russia & $=0.156$ & PIF (India) & $=1.940$ \\
\hline & GIF (Australia) & $=0.564$ & ESJI (KZ) & $=8.716$ & IBI (India) & $=4.260$ \\
\hline & JIF & $=1.500$ & SJIF (Morocce & $=5.667$ & OAJI (USA) & $=0.350$ \\
\hline
\end{tabular}

including «yusrau an-nas» - possessing ability to subordinate people instantly, more preferable and more perfect - «fuzalo va akmal», mujtakhid, which personifies all better qualities of people. In work "Ahkom" Mavardi considers that council of voters should choose as the imam - the head of the country, that one, who possesses the aforementioned qualities and whom they consider more adequately among the other candidates for this post. If the council of voters recommends one worthy person for a post of the head of the country - the imam, among the candidates, then the post of imam - the head of the country, is offered to this person. It is said, that if the person offered for the post of imam - the head of the country, gives the affirmative answer to elective council, then the duty of the imam - the head of the country, is entrusted to this person.

In work of Mavardi "Ahkom" the members of the council «Akhkom al-ukud al-khossa» as a result of announcement to them of the choice of imam - the head of the country, his future management over the country is universally recognized, and he becomes the imam. All Muslim community - «koffat al-umma» should make bayat to him and to obey orders, decisions and instructions of imam - the head of the country. If the answer on a post of imam - the head of the country, is negative, then the acceptance of imam - the head of the country, is considered compelled. Because the choice of imam - the head of the country, should correspond completely to independence principles «akd al-khilofa», on own option of the candidate. If he renounces the post of imam - the head of the country, then this post is offered to other person, who possesses all virtues of the future imam - the head of the country [12].

As Mavardi informs in the work "Akhkom", historically, in the middle Ages if for the post of Caliph - the head of the country, were nominated two persons, and the requirements and qualities of «sivo» demanded from them will be identical, in this case the preference is given to the senior «asannakhuma» on age. If on last criterion, i.e. on age, they are coevals, in this case plays role their authority and influence «kamol al-bulug». According to the doctrine of Mavardi, in this case, in spite of the fact that one of them is more younger than another, contrary to a principle of a choice of the senior from them as imam - the head of the country, the preference is given to younger one, if he is talented, and he is given bayat, i.e. the young and talented person in this case has a full right to become the imam - the head of the country.

According to Mavardi if for the post of imam the head of the country there is nominated one more candidate, and he possesses much knowledge and he is considered as «alam», and the second candidate «ashjaa» - is the brave and courageous military person, and upon request of time and situation, one of them is considered as appropriate on qualities and requirements and is considered as «ruyo» for the post of imam - the head of the country, this person is to be elected.

According to Mavardi, upon request of time, at condition of state needs and positions, it is considered pertinent to reform and suppress revolts and any mutinies, and the need to peace and calmness is considered as an actual problem, the person, who is considered as excellent in respect of force and boldness has a full right «akhak» to take imamat - the country management into his hands [13].

In Mavardi's opinion, for favorable reforming of plots, false opinions, errors according to needs and country situation, it is necessary to prefer «fazl alilm», i.e. the person possessing knowledge in the field of the legislation and considered to be "al-alam" scientist, having in this case a full right «ahakku» for a post of imam - the head of the country.

Basically, it is possible to draw a conclusion that in the doctrine of intention Mavardi means the problems which decisions follow from situation. This fact testifies that he was very skilled politician.

In work "Ahkom" on a post of imam - the head of the country is to be elected that person who has sufficient knowledge for situations settlement in the country during the given period. Just as a presented person embodying features approaching the time and circumstance, the scientist who deduces the people from a difficult situation, the person who has military experience and political -economic knowledge, penetrating into general situations, the person who is considered worthy, and such talented person has a full right to become imam - the head of the country.

According to the doctrine of Mavardi, among candidates the preference should be given to such person who in difficult situations of time, at solving and reforming the inconsistent situations, has sufficient force, bravery, fidelity to the business, knowledge and all-round advantage in experience and is considered comprehensible on a post of imam - the head of the country.

At a choice of imam - the head of the country at a need in a choice of the person possessing all qualities of future imam - the head of the country, when the country appears in difficult situations of false sights of rebels, for reforming of such situations (who struggles idea against idea, knowledge against ignorance) it is necessary without tightening to choose the worthy person on a post of imam - the head of the country. Otherwise, as it is underlined in "Ahkom", the state and a society will fall into degradation.

In the conditions of the present XXI-st century in the world, in various situations and conditions, those, who possess knowledge in the field of economy and the finance, having talent, power and experience in a science and military affair, despite their age, should become the head of the state. Otherwise, decline and crisis in this state and a society is observed. 


\begin{tabular}{|c|c|c|c|c|c|c|}
\hline \multirow{4}{*}{ Impact Factor: } & ISRA (India) & $=3.117$ & SIS (USA) & $=0.912$ & ICV (Poland) & $=6.630$ \\
\hline & ISI (Dubai, UAE & $=0.829$ & РИНЦ (Russia & $=0.156$ & PIF (India) & $=1.940$ \\
\hline & GIF (Australia) & $=0.564$ & ESJI (KZ) & $=8.716$ & IBI (India) & $=4.260$ \\
\hline & JIF & $=1.500$ & SJIF (Morocco & $=5.667$ & OAJI (USA) & $=0.350$ \\
\hline
\end{tabular}

According to Mavardi, every possible ways of an exit from inconsistent situations are specified and according to «kavoidi ahkom li-l-ihtiyor as-sultoniya» - the laws and rules for election of sultan in situations like «uduli bir-rizo li-l-ihtiyor » where one of two imams - candidates on a post of imam - the head of the country is elected, and this problem dares as follows:

1.According to opinion «Ahli ash-shuro» of consultative committee, it is necessary to refuse both inconsistent candidates. In this case, there is no obstacle for search of other candidates on a post of imam - the head of the country. To criticize one of candidates concerning the second, is considered as reforming of such inconsistent situation. In conditions like that, it is necessary to investigate critically the following third candidate.

2.According to opinion of some jurists, a disagreement between candidates on a post of imam the head of the country, their distinctive features: the superiority and advantage of one of these two candidates does not interfere with becoming an imam - the head of the country. To dream about imamate the country leadership is forbidden to nobody. In that case, when the candidate remains not to be elected on a post of imam - the head of the country, there is no obstacle in the statement of not selected candidate.

At occurrence of problems or disagreements between selective council, «ahl al-ihtiyor» - by group of voters and «fukaho» - founders of the law, scientists, it is not considered expedient to demand refusal of the offer from each candidate to whom a post of imam - the head of the country was offered. At solving disagreements between two persons having the identical status and position whose nominee is offered on a post of imam - the head of the country, the opinion of jurists of this group is that:

1.1.According to opinion of the first group between two persons is lot. If one of them wins, to him is given imamat - the country leadership and bayat selected.

1.2.According to opinion of the second group there is no need to throw a lot, and selective council «ahl al-ihtiyor bil-hiyor» without addressing to a lot, intends to make bayat to each of these candidates, they are independent at a choice of this person on a post of imam - the head of the country.

At such responsible situations as the election of imam - the head of the country it is not supposed to throw lot and operate at random, because it is an important state affair, not a gambling. The solution of a problem by such way is illogically and consequently is not supposed.

If selective council, at a choice «ahl al-ihtiyor» has defined one candidate on imamat and this person in turn is considered one of authoritative, powerful and capable persons - «afzal al-zhamoa» of a certain community, there is no obstacle to that members of selective council have transferred bayat to him - says Mavardi [14].

If one more person who considers himself better, proposes his nominee, this situation will not affect imamat of the first selected imam. If the second person makes a claim for a post of imam - the head of the country, and he is considered better", than the operating imam, in this situation it is considered unworthy to deprive imamat from the first selected imam.

The first selected imam has the full legitimate right «ahak» - to remain on the throne. According to the requirement of such situation, i.e. the first preferable imam selected earlier has before himself the best candidate possessing better qualities «mafzul», this situation - to give bayat in this case to the best candidate, is considered as not finished.

In bayat, in spite of the fact that the following best person - «mafzul» has good reasons or a physical illness - «marizan», or a lack - «gaiban» (absence of body organ, a non-working condition, physical inability, a physical defect), if he is closer to heart of people - «akrabu fi-l-kulub» and possesses the superiority and high quality to subordinate the people, the choice of this second person as the imam admits sahih - fair and the nominee of the above-stated candidate having all advantages, is not put on the agenda [15] and is delete off the list.

If bayat is given to the person who possesses quality of "superiority" without physical defects, except the reasons set forth above, if the disagreement on imamat - the country leadership of the person who is much better on some qualities but has a physical defect, it is underlined the law of a management of the candidate and it is shown the following ihtilof distinctions:

1.1.1.According to some scientists and, including Zhohiz [16] to give bayat to imam does not provide handing over the country leadership, electing of the head of the country, negotiating a treaty or condition «akdi imamat» with the head of the country. For, in the matters connected with Shariah and the right as izhtihad searches for new ways, styles, selective as council «ahl al-ihtiyor» should give bayat to the person, the second candidate, to more worthy «mafzul» who has long-term experience as the head of the country and conducts fruitful activity in the country leadership too, rather than to the worthy candidate. In the event that imamat remains for the first selected "worthy" person, handing over the imamat to the second person «mafzul» is not supposed. In this form in Shariah laws, it is not established to do izhtihad.

2.2.2.In opinion of «zhumhur ul-fukaho va-lmutakallimin» jurists and mutakallims, the presence of preferable candidate «mafzul» is considered as clear from the point of view of the law and the most suitable is to do bayat to the first selected candidate «afzal». 


\begin{tabular}{|c|c|c|c|c|c|c|}
\hline \multirow{4}{*}{ Impact Factor: } & ISRA (India) & $=3.117$ & SIS (USA) & $=0.912$ & ICV (Poland) & $=6.630$ \\
\hline & ISI (Dubai, UAE & $=0.829$ & РИНЦ (Russia & $=0.156$ & PIF (India) & $=1.940$ \\
\hline & GIF (Australia) & $=0.564$ & ESJI (KZ) & $=8.716$ & IBI (India) & $=4.260$ \\
\hline & JIF & $=1.500$ & SJIF (Morocco & $=5.667$ & OAJI (USA) & $=0.350$ \\
\hline
\end{tabular}

Finally, in such situations as presence of a nominee of the person «afzal», imamat of «mafzul» persons is not an obstacle. On the contrary, Mavardi results the various examples from the theory and practice concerning a situation at which at presence of imamat of «mafzul» persons, the imam can continue the management affairs of the country, the person «afzal» can supervise over affairs of justice and its activity is considered the same state important, as activity of the head of the country.

According to Mavardi, in the absence of the third alternative person concerning the person «afzal», personifying all advantages of imam - the head of the country, there is even more preferable person «mafzul», that it is considered fair, correct and noteworthy to select him on a post of imam - the head of the country, to do bayat to him.

Mavardi shows the new opinion that a raising of a question of the superiority of candidates on a post of imam - the head of the country, and their level of spiritual advantage perfection should reach perfection and be considered as a high and especially important business.

Meanwhile Mavardi states the point of view that a full right on a post of imam - the head of the country, «istihkak» - among the requirements establishing a hereditary management which has a related character, here again is not available any reasons or terms, noteworthy for an establishment of a full right [17], and puts forward the doctrine about a way of creation of the strong public state, refusing a management of dynasties.

If one person personifies all superiority for becoming an imam - the head of the country and in the absence of the alternative candidate possessing given criteria on a post of imam - the head of the country, in this case it is considered, the nominee of the third candidate on a post of imam - the head of the country is not shown. In this case, it is inadmissible to transfer the power of imamat of the first candidate to the third candidate and to do bayat to him.

The candidate who conducts his activity in the country leadership and personifies all necessary characteristics for a post of imam - the head of the country has the right to propose the nominee for the second term of imam - the head of the country at the meeting «al-mazhlisu ahl al-mashvarat» (specialized council of the Higher election committee).

Mavardi, underlining a choice and intentions in a choice of imam - the head of the country, results opinion that without it, is possible to choose imam the head of the country.

The islamic scientists and scientists of theological schools on a theme of appointment or not appointment of imam - the head of the country inform the following opinions:

1.According to opinion of some Iraq religious scientists, despite treaty provisions of imamat - the country leadership, created by election committee «ahl al-ihtiyor», he can govern the country, and the people can obey to him because the overall objective of election is a choice of imam - the existing head of the country. For, the person who has proposed the nominee should show all qualities for a post of imam - the head of the country.

Here it is possible to consider that Mavardi spoke about founders (imams) of the country. Means, the person who has founded the state, has the legitimate right to be imam - the head of the country for the rest of his life, tells Mavardi.

It is possible to result a lot of examples from histories of the state dynasties as this person has more rights, than the others to become the head of the country which he has created himself, and develops his country independently, providing the peace and rest.

1.According to the majority of religious scientists and mutakkallims, the status of imamat - the person who has come on the power cannot personally establish the imamat - the head of the country because, the imamat - the country leadership is based on election and a mutual consent, and it is handed over to the worthy candidate.

The selective council «ahl al-ihtiyor» with the conclusion of the contract with imam - the head of the country establishes imamat - the country leadership.

Probably community «ahl al-ihtiyor» incorporates in one uniform union and under requirements of delivery of the contract on the state management - akd of imamat their contract on acceptance of the country leadership is considered not perfect.

For, such $a k d$ - the contract is defined only by an election and will be improved.

In this case, some scientists come to such opinion: if there is comprehensively educated person on the questions concerning to cadi, such person is elected as a cadi. Just as, the person who personifies all worthy qualities on a post of imam - the head of the country is subsequently elected on this post.

The difference between cadi and imam - the head of the country consists of that, according to some of people, if only imam personifies all conditions for becoming the imam - the head of the country, he is elected the imam - the head of the country.

If the person embodies all qualities of cadi, he is elected as cadi. A post of cadi is some kind of substitution, and he should operate on behalf of imam - the head of the country.

The post of cadi lawfully is not established while «mustanib» does not demand to be elected as a naib. Becoming the imam - the head of the country is considered the right of mass, and this political right, which merges together between the rights of people and the rights of Allah.

After solving of the questions concerning to imamat - to the country leadership, Mavardi results 


\begin{tabular}{|c|c|c|c|c|c|c|}
\hline \multirow{4}{*}{ Impact Factor: } & ISRA (India) & $=3.117$ & SIS (USA) & $=0.912$ & ICV (Poland) & $=6.630$ \\
\hline & ISI (Dubai, UAE & $=0.829$ & РИНЦ (Russia & $=0.156$ & PIF (India) & $=1.940$ \\
\hline & GIF (Australia) & $=0.564$ & ESJI (KZ) & $=8.716$ & IBI (India) & $=4.260$ \\
\hline & JIF & $=1.500$ & SJIF (Morocco & $=5.667$ & OAJI (USA) & $=0.350$ \\
\hline
\end{tabular}

the following idea about obedience to imam - to the head of the country and about its duties. The special elective conclusions and laws "Ahkom ul-ukudi silthossa» about elections of successor to the throne on a post of the head of the country, candidates, whose nominees are put forward in advance by the elections, all Islamic society should know, how he has come on a post of imam - the head of the country.

But the personality, a name, original position, an origin of imam - the head of the country is considered to be an information known only to council of voters «ahl al-ihtiyor».

For, they on the basis of the existing documentary data elect the Caliph - the head of the country and do bayat to him.

Suleyman ibn Zharir [17] says that the knowledge of a sort and a name of imam - the head of the country is considered as important as knowledge of Allah and Prophet.

According to the majority of the scientists, each person should have sufficient information about imam - the head of the country. There is no need to have thorough and detailed information for each citizen.

But, if for any reasons the citizen is addressing personally to imam - to the head of the country, he has to know a certain name and a clan of imam - the head of the country. Meanwhile, only personally addressing to imam - to the head of the country is comprehensible to own some information on imam - the head of the country. It is like the people addressing to cadi should know some information about cadi.

As they are scientists, khakims and muftis, they give fetva (the decision on any legal matter, taken out by the ecclesiastic on the basis of religion and Shariah doctrines, or the decision establishing acceptability of this or that actions from the point of view of Shariah) about things which are considered khalal (permitted, admitted by Shariah) and kharam (unlawful by Shariah).
For, the person who addresses to cadi on any problem has a full right to receive the general information about cadi. People, having personal problems, claims, and questions to cadi can receive data by a special way. Position concerning the imam - the head of the country is so. If each person from umma has to know special data of a certain sort, names, the person and a sex of the imam, each person who has arrived to the centre from close and distant regions, can receive a detailed information.

This provision can cause a disagreement and objection. Usually intrigues and adversary intrigues are stated in one provision. At business management of umma, the information sufficient for umma is given.

Only at distribution of this information, any revolt and instigation should not rise. Information should not extend without certain legal documents, the basis and fetva.

In such situation those persons who supply the information about imam - the head of the country should receive a special power. By means of this power, they should reform actions of state affairs and contradictions.

\section{Conclusion}

Only personal data can be sufficient if it is accepted conditionally. Data of some people, and original characteristics of councils of people which they have sent, within the limits of the power are considered sufficient, tells Mavardi.

As it has been considered above, the given work and its author narrate how the statehood processes during historical times occurred. For this reason, allround consecutive studying of the given product has an especially great value in a historical source study.

\section{References:}

1. (n.d.). $\mathrm{ANnO}^{\prime} \mathrm{zMK}$ "qo'lyozmalar va nodir nashrlar” bo ‘limi qo ‘lyozmasi, Pv. № 63. $185^{\text {a }}$ varaq. bundan keyin $\mathrm{A}$ : ramziy belgisi bilan yoziladi.

2. (1989). O‘z R FA Sharqshunoslik Instituti qo'lyozmasi, R. № 7228/I (p.390). B: ramziy.

3. (1992). Kuvayt. (p.327). K: ramziy.

4. Bayrut, L. (1994). Ebu'l-Haan Habib elMa'verdi. El-Ahka'mu's-Sultaniye/Seviren: Ali Shafak. - Istanbul.

5. (n.d.). Bedir Yayinevi. - 504 v. Turkiya. T.

6. (n.d.). A: $-4^{\text {a }}$; B: $-3^{\text {a }}$-varaq. K: - B. 4 ; L: - B. 4; T: - B. 31 .
7. (n.d.). Qarang: “Al-Movardiyning "Al-Ahkom as-sultoniya va-1-valoyot ad-diniya" asari davlatchilikka oid muhim manba (X -XI asrlar)" mavzusidagi dissertatsiya materiallaridan foydalanildi. (p.250). nashrda.

8. (n.d.). A: $-4^{\mathrm{a}}$; B: $-3^{\mathrm{a}}$-varaq. K: - B. 4 ; L: - B. 4; T: - B. 31 .

9. (n.d.). A: $-4^{\mathrm{a}}$; B: $-3^{\mathrm{a}}$-varaq. K: - B. $4 ; \mathrm{L}:-$ B. 4; T: - B. 31 .

10. (n.d.). A: $-4^{\mathrm{a}}$; B: $-3^{\mathrm{a}}$-varaq. K: - B. $4 ; \mathrm{L}:-\mathrm{B}$. 4; T: - B. 31 .

11. (n.d.). A: $-4^{\mathrm{a}} ; \mathrm{B}:-3^{\mathrm{a}}$-varaq. K: - B. $4 ; \mathrm{L}:-\mathrm{B}$. 4; T: - B.31. 


\begin{tabular}{llllll} 
& ISRA (India) $=\mathbf{3 . 1 1 7}$ & SIS (USA) $=\mathbf{0 . 9 1 2}$ & ICV (Poland) & $\mathbf{= 6 . 6 3 0}$ \\
Impact Factor: & ISI (Dubai, UAE) $=\mathbf{0 . 8 2 9}$ & PUHЦ (Russia) $=\mathbf{0 . 1 5 6}$ & PIF (India) & $=\mathbf{1 . 9 4 0}$ \\
& GIF (Australia) $=\mathbf{0 . 5 6 4}$ & ESJI (KZ) & $\mathbf{8 . 7 1 6}$ & IBI (India) & $=\mathbf{4 . 2 6 0}$ \\
& JIF & $\mathbf{1 . 5 0 0}$ & SJIF (Morocco) $=\mathbf{5 . 6 6 7}$ & OAJI (USA) & $\mathbf{0 . 3 5 0}$ \\
\hline
\end{tabular}

12. (n.d.). A: $-3^{\text {b }}$; B: $-3^{\text {a }}$-varaq; K: - B. $6 ;$ L: - B. 7; T: - B. 32-34

13. (n.d.). A: $-4^{\mathrm{a}} ; \mathrm{B}:-3^{\mathrm{a}}$-varaq; K: - B. 7 ; L: - B. 7; T: - B. 34-37.

14. (n.d.). A: $-4^{\text {a }}$; B: $-3^{\text {a }}$-varaq; K: - B. 8; L: - B. 8; T: - B. 34-37.
15. (n.d.). A: $-4^{\mathrm{a}}$; B: $-3^{\mathrm{a}}$-varaq; K: - B. $8 ; \mathrm{L}:-\mathrm{B}$. 8; T: - B. 34- 37 .

16. (n.d.). 11. A: $-5^{\mathrm{a}}$; B: $-4^{\mathrm{a}}$-varaq; K: - B. 9; L: B. 9; T: - B. 34-37.

17. (n.d.). 11. A: $-5^{\mathrm{a}}$; B: $-4^{\mathrm{a}}$-varaq; K: - B. 9; L:B. $9 ;$ T: - B. $34-37$. 